\title{
Developing English for Academic Purposes (EAP) teaching materials: a needs analysis of novice teachers
}

\author{
Larissa Goulart da Silva \\ University of Warwick \\ goulart.larissa@hotmail.com \\ Ana Paula Seixas Vial \\ Universidade Federal do Rio Grande do Sul \\ anapvial@gmail.com \\ Simone Sarmento \\ Universidade Federal do Rio Grande do Sul \\ Simone.sarmento@ufrgs.br
}

\begin{abstract}
The Language without Borders (LwB) Programme is an educational policy which aims at promoting English learning at universities as well as promoting opportunities for teacher development. LwB teachers have to prepare their own English for Academic Purposes (EAP) teaching materials. Taking this into account, we seek to understand how the LwB Programme prepares these teachers to create EAP materials and if they encounter any difficulties. A needs analysis was carried out through online surveys and semi-structured interviews. The former was sent to LwB teachers from all over Brazil, and the latter was conducted with teachers from one university. Based on the results we suggest some topics that could be addressed in the pedagogical meetings to address these teachers' needs.
\end{abstract}

Keywords: English for academic purposes, teacher training, Languages without Borders.

\section{Resumo}

O Programa Idiomas em Fronteiras (IsF) é uma política educacional que busca promover a aprendizagem de inglês na universidade e ser uma oportunidade de formação de professores, pois os professores-bolsistas do IsF devem preparar seu próprios materiais didáticos de Inglês para Fins

Horizontes de Linguística Aplicada, ano 16, n. 1, 2017 
Developing English for Academic Purposes...

Acadêmicos (IFA). Levando isso em consideração, buscamos entender como o Programa IsF prepara esses professores para elaborar materiais de IFA e se encontram dificuldades. Para tanto, foi conduzida uma análise de necessidades através de questionários online e entrevistas. Os questionários foram enviados para professores IsF de todo o Brasil e as entrevistas foram realizadas com professores de uma universidade. Com base nos resultados, sugerimos tópicos que podem ser trabalhados nas reuniões pedagógicas para responder às necessidades dos professores.

Palavras-chave: Inglês para fins acadêmicos; formação de professores; Idiomas sem Fronteiras.

\section{Introduction}

Taking into account the ongoing process of internationalization of Brazilian higher education (HE) (CARNOY, 2013) it is necessary to understand how language teachers involved in this process teach academic English for internationalization. This paper explores how Languages without Borders $(\mathrm{LwB})$ teachers are being prepared to deliver English for Academic Purposes (EAP) classes. LwB teachers are novice teachers who share the goal to prepare Brazilian HE students and researchers to participate in international academic forums in English. Nevertheless, there is not enough data regarding how these teachers are trained to teach EAP in their undergraduate programs or at LwB itself. This way, we have conducted surveys and interviews with $\mathrm{LwB}$ teachers to form a better understanding of EAP teacher development practices occurring in LwB throughout Brazil.

In order to study the needs of novice EAP teachers when preparing materials to be used in their EAP lessons, we seek to answer the following research questions.

1) What is the profile of $\mathrm{LwB}$ teachers in different universities in Brazil?

2) What activities are developed as part of their training in the LwB centres?

3) What are some of these teachers' difficulties when preparing EAP materials to be used in the LwB context?

4) What training activities would they like to be developed in the pedagogical meetings in order to help them prepare their classes? 
Our interest on this topic emerges from our current practice as researchers of Brazilian EAP teacher development, and from our previous experience as former EAP teachers and coordinator in the context of the LwB Programme. We hope that the results of this investigation will provide insights into activities and practices that could be developed in EAP teacher training settings, such as the LwB Programme.

This paper is divided innto six sections. The next section (2) discusses the LwB Programme with reference to its development as a policy and teaching objectives. The following section (3) introduces a literature review of EAP teacher training and the subsequent two sections (4 and 5) offer an overview into the results of the surveys and interviews. Finally, in the last section (6) we draw some conclusions and present some suggestions of topics that could be addressed in the pedagogical meetings of this Programme.

\section{Languages without Borders - English: an overview}

The aim of this section is to contextualize the Languages without Borders Programme, as this is the setting of all the research participants. LwB is a Federal government policy present in 63 Brazilian federal universities (BRAZIL, 2015). This policy first emerged as a branch of the Science without Borders (SwB) Programme, which was a scientific mobility initiative created in 2011. Initially, most students participating in this exchange Programme selected Portugal as their country of destination due to the fact that both countries share Portuguese as their main language of interaction. Nevertheless, the goal of the SwB Programme was to promote academic exchanges between Brazilian universities and universities of excellence abroad. When discussing SwB, Neto and Senhoras (2014, n.d.) stated that

Brazilian students do not go to higher education institutions identified as the best in comparative rankings, however they rather go to institutions in Portugal and Spain, given that the knowledge of the international language, English, is 
Developing English for Academic Purposes...

identified as a problem in the Science without Borders Programme selection.

As a solution for this linguistic barrier, in 2012, the Brazilian ministry of education created the LwB Programme. The objective of this Programme is to improve the language proficiency of the academic community in universities while also being an opportunity for teacher education. After its foundation, the language centres (called NucLi) were established in several universities in Brazil. Through the Languages without Borders all university academic community (staff, students, and professors) can attend free English classes. Although this paper takes into account the face-to-face classes, it is worth noting that the LwB is composed of three initiatives: an online English teaching platform (My English Online) ${ }^{1}$; the administration of Test Of English as a Foreign Language Institutional Testing Program (TOEFL ITP) tests for the university community; and the face-to-face English classes. It is also important to mention that even though the LwB is present in a considerable number of universities, the Programme is decentralized; therefore, not all universities adopt the same practices regarding teaching and teacher training. The number of teachers and coordinators, for example, varies in each university, as well as the type of English courses offered.

It is important to note that, unlike most English courses, LwB classes are not supposed to have a pre-established sequence of courses, in which students progress from English pre-intermediate to advanced, for instance. LwB promotes students' autonomy by allowing them to choose their courses according to their needs and create their own curriculum path.

Considering LwB teachers, they need to be enrolled in a teaching degree programme and have a good command of the English language attested by a proficiency test such as IELTS, or TOEFL. These teachers have to teach three English classes of four hours a week, participate in weekly pedagogical trainings and prepare teaching materials. The focus of this paper is the activities developed in the pedagogical meetings and how they help teachers prepare EAP materials. Nevertheless, considering that LwB centres have a certain

1 - http://www.myenglishonline.com.br/

Horizontes de Linguística Aplicada, ano 16, n. 1, 2017 
degree of autonomy, we expect to encounter different practices being developed in these meetings. Hence, the surveys conducted for this investigation also explore to what extent these practices are different in each LwB centre.

The aim of this section was to contextualize the LwB Programme and provide an overview on its peculiarities. The next section presents the literature in the field of EAP teacher training.

\section{EAP teacher training}

This paper addresses the needs of EAP teachers, therefore in this section we explain what is understood by EAP in this study. Johns and Price-Machado (2001) characterize it as English instruction focused on students' real needs in order to achieve a determined goal. According to Strevens (1977), EAP is a branch of English for Specific Purposes (ESP). However, EAP is not the only derivation of ESP. Robinson (1991) argues that ESP can be divided into two branches: EAP and English for Occupational Purposes (EOP). EOP can be associated to business English, or English for Law, for example. For the purposes of this paper, we use Hyland and Hamp-Lyons' (2002, p.02) definition of EAP, which says that "English for Academic Purposes refers to language research and instruction that focuses on the specific communicative needs and practices of particular groups in academic contexts". Finally, EAP students in the context discussed here are university students or researchers involved in the academic discourses in their fields of study.

Hyland and Hamp-Lyons (2002, p.02) argue that EOP, ESP, and EAP implicate different teaching practices when compared to those used to teach general English. They state that:

[T]eachers have also come to acknowledge that teaching those who are using English for their studies differs from teaching those who are learning English for general purposes only. It is also different from teaching those who are learning for occupational purposes (HYLAND; HAMPLYONS, 2002, p.02). 
Developing English for Academic Purposes...

Hence, these acronyms are not only related to students' objectives in learning the language, they also relate to the methodologies and practices used to teach it. Regarding ESP and EAP teaching, Johns and Dudley-Evans (1991, p.305) argue that "ESP requires methodologies that are specialized or unique". In addition, according to these authors, EAP classes should have "different approaches than those found in general English classes". Robinson (1991, p.04) supports these authors' claims, and suggests that one of the main differences of EAP and general English teaching is that EAP "activities can have a truly authentic purpose related to students' target needs".

Several researchers (BELCHER, 2004; HYLAND; HAMPLYONS, 2002; CRISTOVÃO; BEATO-CANATO, 2016; HYLAND, 2016) discuss these different pedagogical practices required from an EAP teacher. Belcher (2004) suggests that EAP teachers need to bring empirical data to the classroom and be able to adapt tasks and pedagogical materials according to students' needs. Cristovão and Beato-Canato (2016, p.60), on the other hand, claim that EAP teachers have to be able to "analyse the communicative situation, evaluate students' difficulties, perceive the origins of their needs, conduct needs' analysis, study the genres the student will need, and find materials for the lessons". It is noticed that these authors suggest that EAP lessons should emphasize real communicative situations and be tailor-made for students' needs. Furthermore, considering EAP students, Hyland (2016) argues that "EAP students are studying English for a particular practical need which means curriculum designers study target language features in specific academic contexts, and teachers focus on these features in their classroom." Certainly, in the ideal world, that would happen, but in the case of the LwB Programme, usually teachers are the curriculum designers and the ones who bring the language to the classroom as well. As expected, they sometimes encounter difficulties when performing both of these roles. Therefore, this paper tries to provide some suggestions for teacher development that could help teachers in these contexts.

In sum, these previous investigations on EAP methodology suggest that, in order to teach EAP, it is necessary for the teacher to use different practices (and activities) in the classroom than those adopted when teaching general English. Nevertheless, these teaching guides do 
not address the issue of how novice EAP teachers can implement these practices in their classrooms.

According to research conducted by Cristovão and BeatoCanato (2016), initial teacher training in Brazil usually emphasizes general English teaching only. In addition, most English teaching degrees offered by Brazilian universities do not have a specific EAP course in their curricula. These authors argue that undergraduate students have access to some sort of EAP if they assume the role of assistant tutors in EAP classes at their universities. Nevertheless, this activity usually occurs on a volunteering basis, and it is not extended to all students. These researchers also state that

[T] here is a need to train EAP teachers taking into account the specificities of EAP teaching practices. A teacher with general training will have to make many adaptations in order to teach in EAP contexts, which has a growing need for teachers. (CRISTOVÃO; BEATO-CANATO, 2016, p.67).

Yet, the need for specific EAP teacher training is not only an issue in Brazil, but also in other contexts as Jordan (2002) suggests. Usually teacher training courses promote an overview of methodologies for the teaching of general English without taking into consideration the teaching of English for academic or professional purposes. Moreover, Hyland and Hamp-Lyons (2002, p.02) point out the fact that most EAP teachers are nonnative English speakers, and that "the needs of these nonnative teachers are different from those of native speakers, and this recognition has led to new developments in EAP materials and teacher training courses".

Another point of concern for EAP practitioners is whether teachers should emphasize general academic English or the academic language of one specific area. Hyland (2016) discusses this issue stating that

[S]ome teachers have sought to tailor instruction to students' disciplinary subject matter needs, while others have tried to identify common ground among students and teach what Hutchinson and Waters (1980) referred to as 'general linguistic competence'. 
Developing English for Academic Purposes...

In the context of the LwB Programme, teachers generally adopt a general academic linguistic competence approach in their classrooms due to the fact that classes are not separated according to students' fields of study.

Finally, given the studies presented above it is possible to assume that EAP teachers require specific training to fulfil their course aims. Nevertheless, according to previous studies, pre-set teacher development courses do not address this issue. Therefore, EAP teachers have to learn during their practice. Considering this, the LwB, through its pedagogical meetings, has the potential to fulfil this gap. Hence, we have set out to explore this context as a means to contribute to the research in the field of EAP and teacher development in Brazil.

The aim of this section was to present previous studies in the field of EAP and EAP teaching. The next section discusses the results of the survey conducted with LwB teachers from all over Brazil.

\section{Surveys}

In this section, we present and discuss the answers to the survey. The participants were taking part in an online teacher development course, which was part of their activities in the LwB Programme. All participants in this course received an email with the link to the survey. The first question was a consent form, explaining the aims of this investigation and informing teachers that they could withdraw their participation at any time. Only the participants who agreed with the terms in the consent form answered the survey. We obtained 52 responses from 24 different $\mathrm{LwB}_{\text {centres }}{ }^{2}$ in Brazil. The map below marks with a star the universities where the LwB centres are located.

Figure $01-L w B$ centres' locations

${ }^{2}$ The map displays 18 stars because some cities contain more than one university with an LwB centre. 
Larissa Silva; Ana Paula Vial; Simone Sarmento

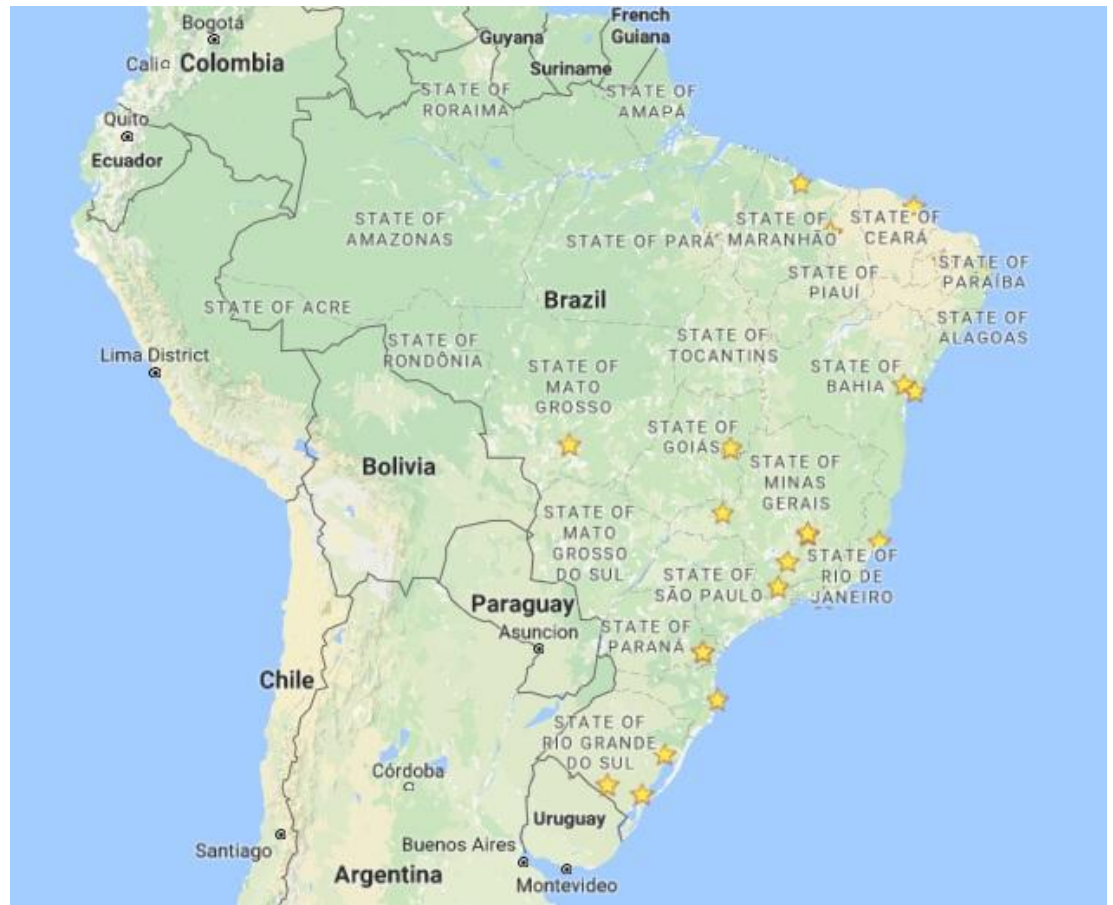

The survey contained 17 questions. However, some of them were follow-up questions, therefore not all teachers answered all questions. The following paragraphs present the questions, the teachers' answers and a brief discussion. 
Developing English for Academic Purposes...

Figure 02 - Question 1. How long have you been a teacher at the LwB Programme?

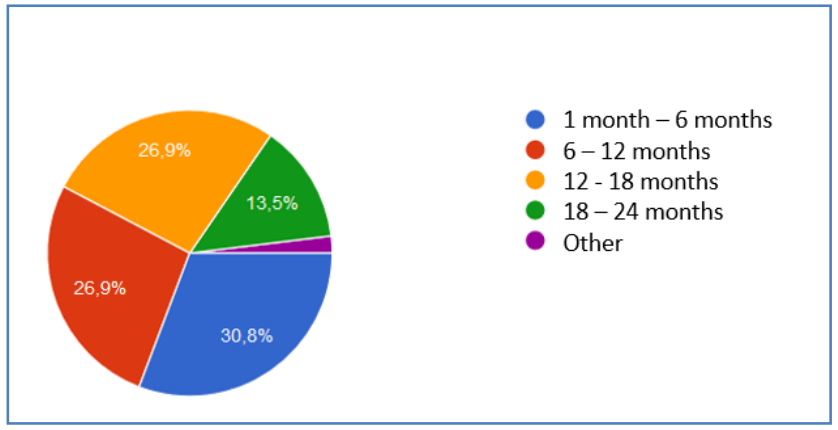

The majority of teachers had one year or less of experience in the Programme. It is worth mentioning that LwB teachers are usually hired for a maximum of a 24 month-period.

Figure 03 - Question 2. What is your level of education?

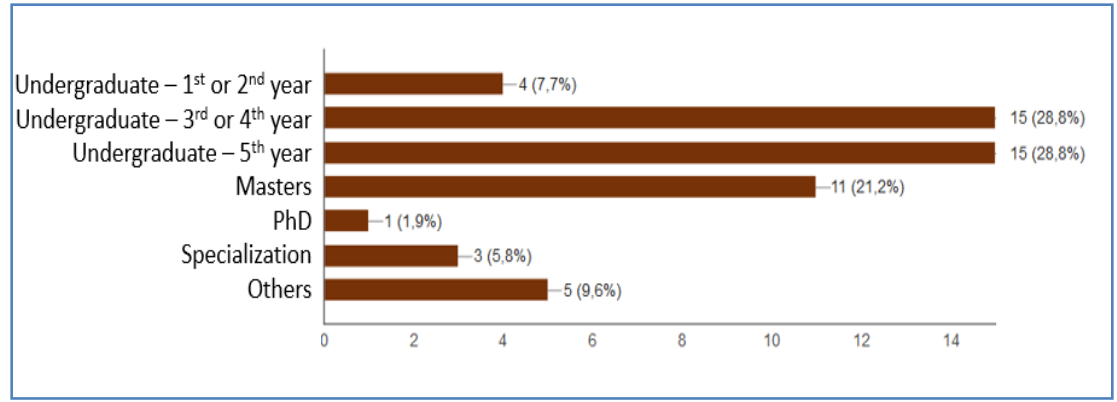

The bar chart above suggests that most LwB teachers (34 teachers in total) are undergraduate students, followed by Master's students. It is common for LwB teachers to be in the middle or final years of their undergraduate course, as in the beginning of their undergraduate course they do not have the necessary English proficiency to become a LwB teacher. 
Figure 04 - Question 3. Have you ever taught EAP classes in the LwB Programme?

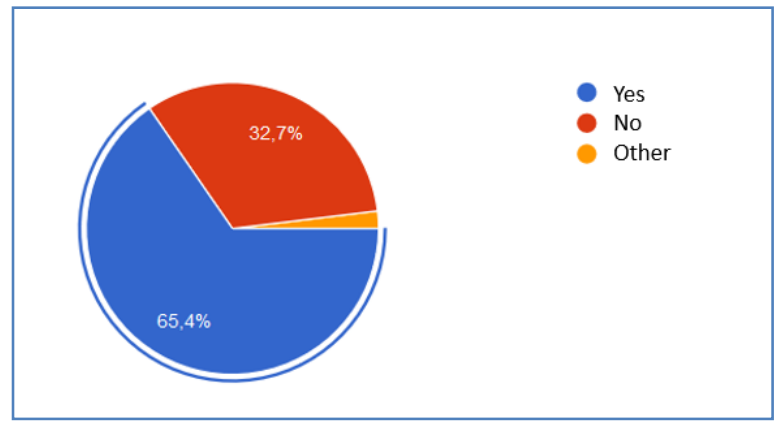

We have included a question here (What was the name of the EAP course you have taught?) in order to select only the teachers who had already taught EAP classes to continue the survey. As previously mentioned, general English classes are offered as part of the LwB Programme, although they are not its focus. From our respondents 34 teachers had already taught EAP classes, while 17 teachers had not.

The figure below presents the title of the EAP course that these teachers have taught. These courses were categorized according to their types in order to allow for a better understanding of the variety of courses offered throughout Brazil.

Figure 05 - Title of EAP courses

\begin{tabular}{|l|c|}
\hline \multicolumn{1}{|c|}{ Name } & Type \\
\cline { 1 - 1 } English for academic purposes & \multirow{2}{*}{$\begin{array}{c}\text { General } \\
\text { Academic } \\
\text { English }\end{array}$} \\
\cline { 1 - 1 } English for professional and academic purposes & \\
\cline { 1 - 2 } English for academic Exchange & \multirow{2}{*}{$\begin{array}{c}\text { Skill-based } \\
\text { Academic }\end{array}$} \\
\cline { 1 - 2 } English language for academic interactions & \\
\hline $\begin{array}{l}\text { Introduction to the development of academic skills: } \\
\text { reading and writing }\end{array}$ &
\end{tabular}


Developing English for Academic Purposes...

\begin{tabular}{|c|c|}
\hline Reading and discussion of texts in English & \multirow[t]{12}{*}{ English } \\
\hline Reading for academic purposes & \\
\hline Reading academic texts & \\
\hline Academic reading and writing & \\
\hline English grammar for academic purposes & \\
\hline English for academic writing & \\
\hline Writing in English for proficiency tests & \\
\hline Writing strategies in English & \\
\hline Listening for academic purposes & \\
\hline Oral comprehension for academic purposes & \\
\hline General and academic conversation & \\
\hline Conversation for professional and academic purposes & \\
\hline $\begin{array}{l}\text { English for academic purposes: article reviews and } \\
\text { abstracts }\end{array}$ & \multirow{2}{*}{$\begin{array}{l}\text { Genre Based } \\
\text { Academic } \\
\text { English }\end{array}$} \\
\hline Writing practice of academic genres & \\
\hline English for academic purposes for health professionals & \multirow{2}{*}{$\begin{array}{l}\text { Discipline } \\
\text { specific } \\
\text { Academic } \\
\text { English }\end{array}$} \\
\hline $\begin{array}{l}\text { English for specific purposes: agronomy, engineering, } \\
\text { socio-biodiversity and sustainable development }\end{array}$ & \\
\hline
\end{tabular}

As previously mentioned, LwB centres have the autonomy to develop their courses to suit the needs of the academic community in each university. The table above represents the plurality of EAP courses created in the context of the LwB Programme. We can also observe that some courses are organized according to skills (reading, 
writing, speaking or listening), while some courses are organized based on academic genres or different disciplines.

Figure 06 - Question 5. In these EAP courses, did you have students from different areas?

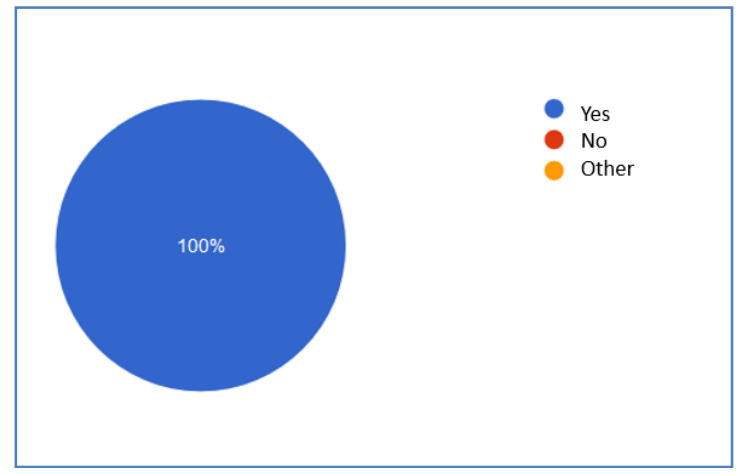

As expected, in the EAP classes taught by these teachers, students from different areas were mixed together. The reason for this is that students are divided according to their level of English and personal interest in the course theme rather than by content areas. Therefore, EAP classes in the context of LwB have to meet the needs of several areas in one course, which can be demanding for the teachers. This issue is explored in question number 11 .

Figure 7 - Question 6. In these EAP courses, what was the students' level of proficiency?

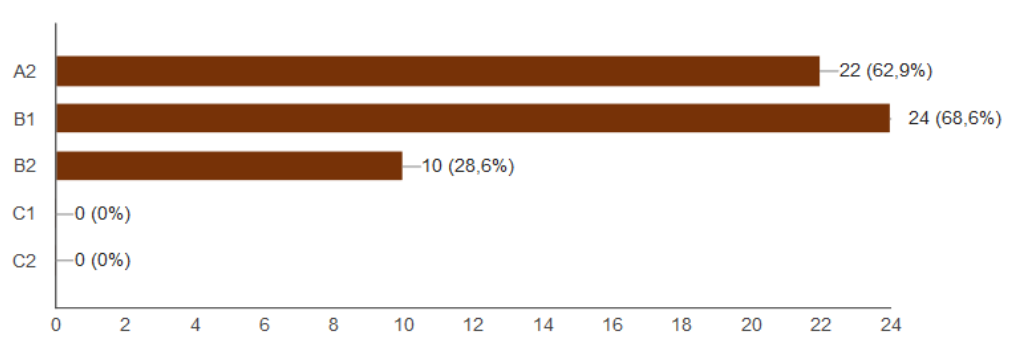


Developing English for Academic Purposes...

Students need to take the TOEFL ITP $^{3}$ test before enrolling in one of the classes. Hence, teachers are aware of their students' level and they have a relatively homogeneous class in terms of proficiency. Nevertheless, as we can notice, most of the students have a beginner or pre-intermediate level. This issue is also explored in questions 11 and 12.

Figure 08 - Question 7. What kind of teaching materials have you used in your EAP classes?

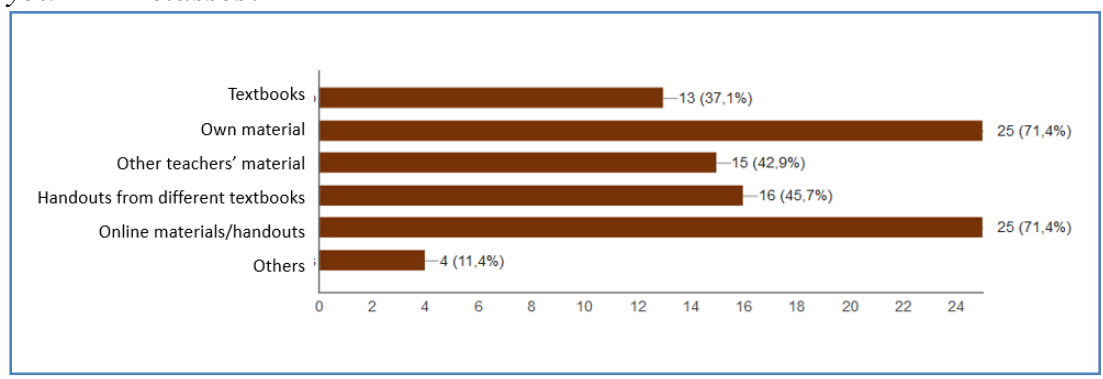

We included this question in the survey as we were interested in understanding whether teachers developed their own material or used pre-prepared materials. It was our perception, as former LwB teachers, that the Programme encourages the production of new teaching materials or the adaptation of tasks or textbooks. The answers to the question corroborate our perception: most claim that they create their own material or look for materials online. In addition, we can perceive that textbooks are the least used resource. This might be due to the fact that some LwB courses are short-term and teachers would not be able to use most of the activities in a textbook, therefore they opt to prepare their own material rather than ask students to buy a textbook that will not be used in its entirety. Another possible reason is that it is difficult to find an EAP textbook that fulfils the needs of a particular academic setting.

${ }^{3}$ The TOEFL ITP was a requirement for students at the time when the study was conducted. A different leveling test is required now.

Horizontes de Linguística Aplicada, ano 16, n. 1, 2017 
Figure 09 - Question 8. In your LwB centre, do you have to prepare your own EAP teaching materials?

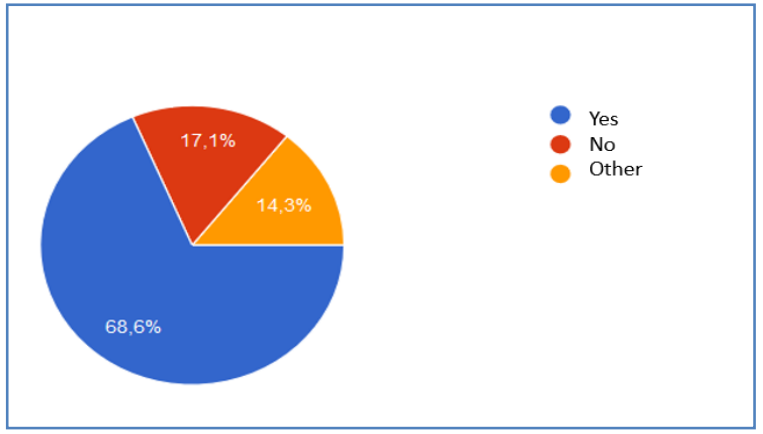

We wanted to investigate if all LwB centres encouraged teachers to develop their own materials. As we can see 24 teachers $(68,6 \%)$ had to prepare their own EAP teaching materials as part of their activities in the Programme.

Figure 10-Question 9. Where do you prepare your EAP classes?

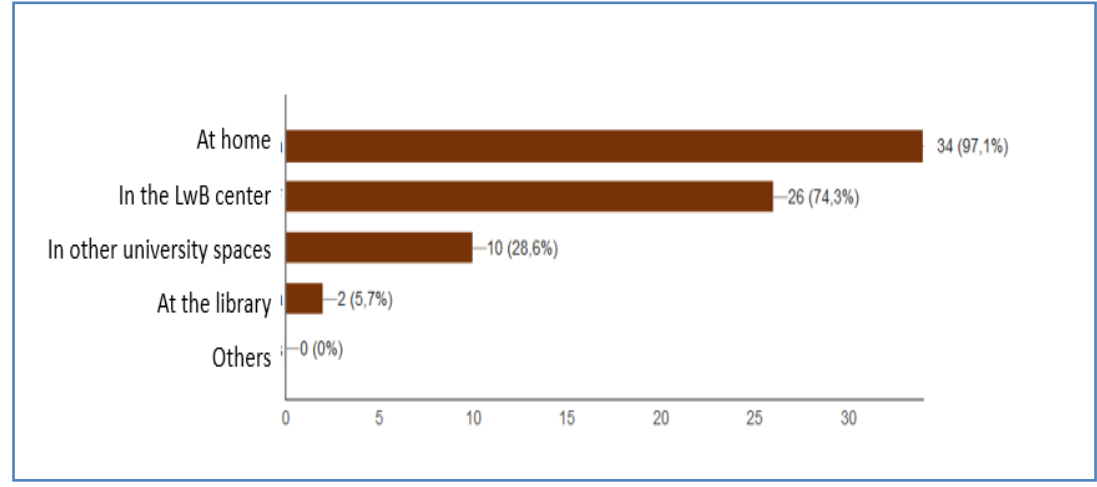

In some LwB centres teachers have access to resources like textbooks, handbooks of activities, and ELT magazines that might help them prepare their classes. Hence, the aim of this question was to explore where teachers chose to prepare their teaching materials so as to investigate if these resources were being used. As reported, teachers mainly prepare their classes at home, followed by the LwB centre and other university spaces. 
Developing English for Academic Purposes...

Figure 11 - Question 10. Do you prepare teaching materials with other people?

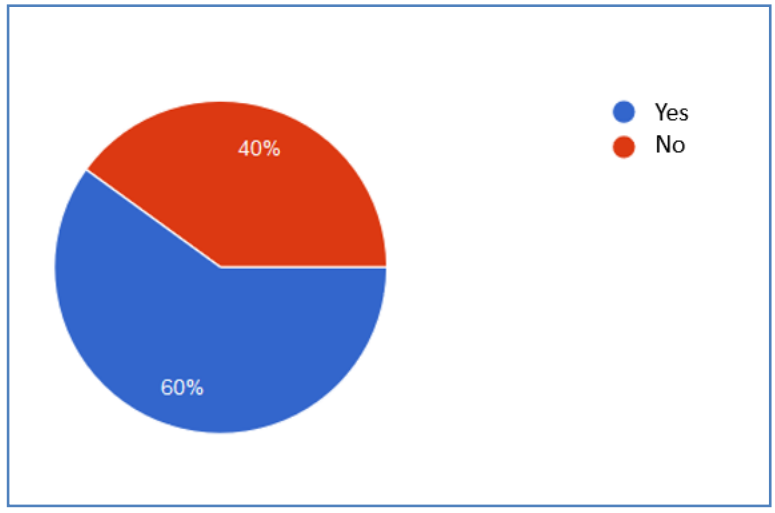

Figure 12 - Question. 10.a - With whom?

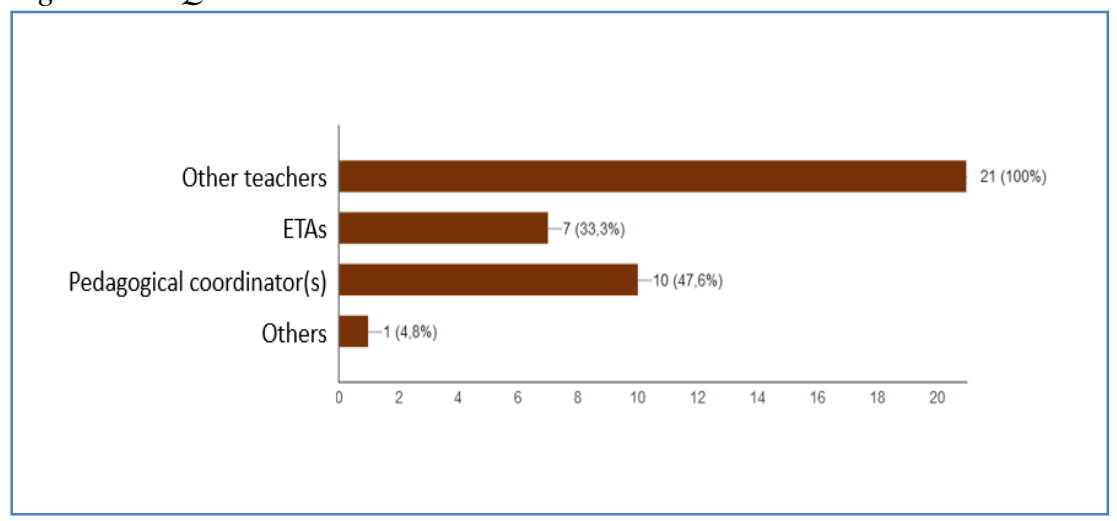

Question 10 addressed the issue of whether LwB teachers were working alone to develop their EAP materials or with other teachers; 21 teachers $(60 \%)$ worked with other people to develop their materials. In addition, teachers work mainly with other teachers when preparing their classes, followed by the pedagogical coordinators. It is worth explaining that some LwB centres have English Teaching Assistants 
(ETAs) ${ }^{4}$ who can help teachers prepare materials and might participate in their classes. However, according to the responses, ETAs participate less than pedagogical coordinators in the development of teaching materials.

Figure 13 - Question 11. What difficulties do you encounter when preparing EAP materials?

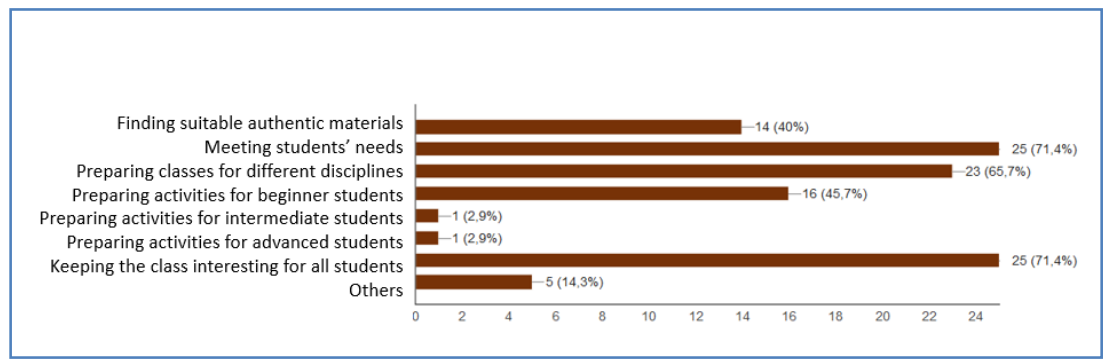

Question 11 provided a series of options for teachers to select their difficulties when preparing EAP materials. The results show that the teachers consider it difficult to meet students' needs and keep the class interesting for all students. These two aspects might be associated to the fact that teachers have students from different disciplines in the same group, which is corroborated by the third most voted option "preparing classes for different disciplines". The research participants might encounter some difficulties to prepare classes that have to meet the needs of health sciences' students while also keeping the class interesting for history students, for instance. Furthermore, teachers also select as one of their main difficulties "preparing EAP activities for beginner students and finding authentic materials". The issues mentioned in response to question 11 are explored in more depth in the interviews.

4 ETAs are US assistants who come to assist the LwB Programme through the Fulbright Programme of scholarships. They cannot teach regular courses, but they can co-teach with the Brazilian teachers and offer short courses and workshops for the academic community. 
Developing English for Academic Purposes...

Figure 14 - Question 12. Is there any difference in how you develop EAP materials for different levels of English proficiency? Which one(s)?

\begin{tabular}{|c|c|}
\hline Answers & \\
\hline No (3 answers) & \\
\hline Pair work in class. & \multirow{7}{*}{$\begin{array}{l}\text { Beginner } \\
\text { students }\end{array}$} \\
\hline $\begin{array}{l}\text { Using authentic materials with A2 students is more } \\
\text { difficult. }\end{array}$ & \\
\hline $\begin{array}{c}\text { For A2 levels it is easier to focus on specific topics than } \\
\text { on skills. }\end{array}$ & \\
\hline Auxiliary materials (for A2 students). & \\
\hline Materials that can be understood by the students. & \\
\hline $\begin{array}{l}\text { The level of English needs to be adequate, otherwise } \\
\text { there is lack of interest. }\end{array}$ & \\
\hline Linguistic competence. & \\
\hline $\begin{array}{l}\text { The level of requirement is different for each level of } \\
\text { proficiency. }\end{array}$ & \multirow{7}{*}{$\begin{array}{l}\text { Levels of } \\
\text { difficulties } \\
\quad \text { and } \\
\text { adaptation }\end{array}$} \\
\hline Vocabulary level of difficulty & \\
\hline $\begin{array}{l}\text { The topics would not be different, but the linguistic } \\
\text { resources. Comparisons between Portuguese and English } \\
\text { corpora when there are problems related to generalization of } \\
\text { rules in the L1 when learning the L2. }\end{array}$ & \\
\hline $\begin{array}{l}\text { It is necessary to adapt the content, for example, by } \\
\text { changing the examples of the same topic. }\end{array}$ & \\
\hline Different types of exercises & \\
\hline According to the needs of the students & \\
\hline Level of difficulty and size of texts, videos and audios & \\
\hline
\end{tabular}

Horizontes de Linguística Aplicada, ano 16, n. 1, 2017 


\begin{tabular}{|c|}
\hline used in class \\
\hline Complexity of themes \\
\hline $\begin{array}{l}\text { For higher level students (B1 onwards) the material } \\
\text { needs to be more challenging and the writing needs to be longer. } \\
\text { For A2 students, the focus needs to be on paragraph construction } \\
\text { and their internal organization. }\end{array}$ \\
\hline $\begin{array}{l}\text { Prepare classes based on what students demonstrated in } \\
\text { the previous ones and on what we expect them to achieve at the } \\
\text { end of each lesson }\end{array}$ \\
\hline
\end{tabular}

As it is possible to notice in the table above, teachers recurrently refer to the difficulties basic level students face to understand authentic materials. We can only hypothesize that teachers were not trained to prepare teaching materials for basic level EAP students. Furthermore, teachers refer to adapting the topics, contents, or exercises brought to class according to students' level of proficiency, showing that teachers are aware of the different needs of basic and intermediate students.

Figure 15 - Question 13. What do you do to meet the specific needs of students from different areas of knowledge when developing your EAP materials?

\begin{tabular}{|c|c|}
\hline Answers & Category \\
\cline { 1 - 2 } Variation of themes and topics & \\
\cline { 1 - 2 } Bring videos to start discussion & \\
\cline { 1 - 2 } $\begin{array}{c}\text { Use the materials from the workshops promoted by the English } \\
\text { Teaching Assistants (ETAs) as input for text production and } \\
\text { oral presentations }\end{array}$ & Differences \\
\hline Bring texts from their areas of study & \\
\hline $\begin{array}{c}\text { Bring input from their areas and adapting them with what is } \\
\text { proposed in the didactic materials }\end{array}$ & \\
\hline
\end{tabular}


Developing English for Academic Purposes...

\begin{tabular}{|c|c|}
\hline Students suggest readings & \\
\hline $\begin{array}{l}\text { Discussions on the epistemological and methodological } \\
\text { differences between the areas }\end{array}$ & \\
\hline Students present their works & \\
\hline $\begin{array}{l}\text { Principles for writing texts: coherence, cohesion, use of } \\
\text { vocabulary }\end{array}$ & \multirow{6}{*}{ Similarities } \\
\hline Clear objectives that attend the needs of everyone & \\
\hline Work with the needs they have in common & \\
\hline Relevant topics for all areas & \\
\hline Needs analysis on the first day of class & \\
\hline Adequate materials for each level & \\
\hline
\end{tabular}

According to the answers, teachers adopt two opposed strategies in order to circumvent this issue. Some teachers focus on the similarities of academic language, teaching what Hyland (2008) considers to be general academic English, while others try to cater for the specificities of some fields of study when developing their materials.

Figure 16 - Question 14. Do you (does your LwB centre) make the teaching materials developed available?

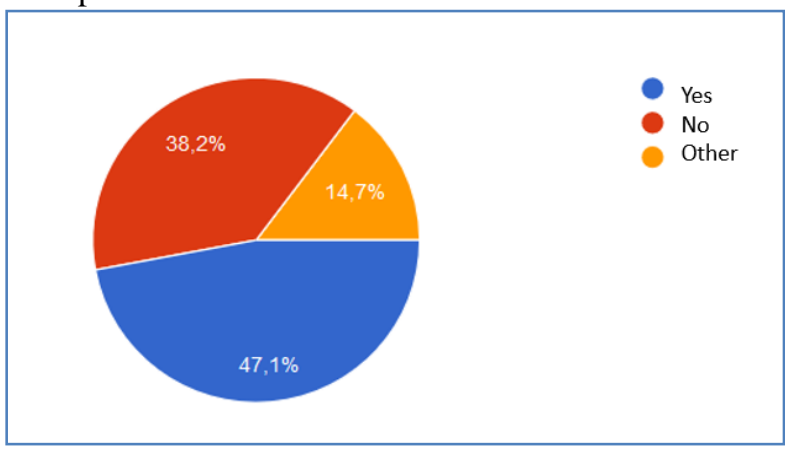

Horizontes de Linguística Aplicada, ano 16, n. 1, 2017 
Larissa Silva; Ana Paula Vial; Simone Sarmento

Figure 17 - Question 14.a - Where do you share the materials you develop and/or use in class?

\begin{tabular}{|c|c|}
\hline Moodle & Physical folders \\
\hline Google Drive & Facebook \\
\hline Dropbox & I do not know \\
\hline E-mail & Shared computer \\
\hline
\end{tabular}

Considering that most teachers have to prepare their own teaching materials, as it was pointed out in question 08 , we were interested to know if teachers shared these materials that they had developed with other colleagues. Hence, question 14 addressed this issue. As we can see, in some centres teachers share the materials created through Moodle, Google Drive or other tools. However, it is also possible to notice that a considerable amount of teachers or centres do not make their teaching materials available.

Figure 18 - Question 15. Does your LwB centre have weekly pedagogical meetings?

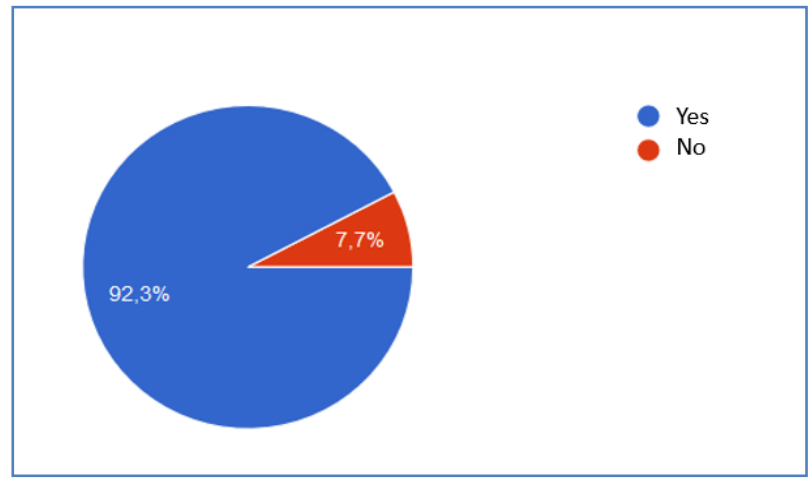

Although participation in pedagogical meetings are part of the LwB teachers' obligations, in some LwB centres due to the lack of a pedagogical coordinator it is not possible to conduct a teacher development session every week. Therefore, it seems positive that most of the teachers who replied to our surveys state that they have 
Developing English for Academic Purposes...

weekly pedagogical meetings. It is also important to notice that the online course these teachers were taking had the purpose of complementing the pedagogical development that teachers have in their own LwB centre.

Figure 19 - Question 16. In these pedagogical meetings is there any development regarding EAP teaching materials?

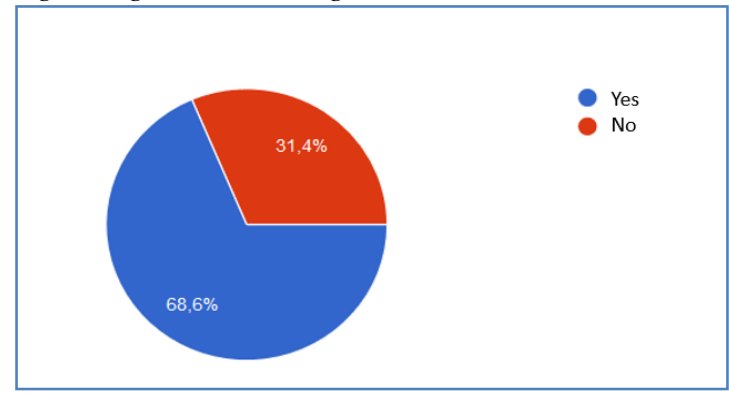

The objective of question 16 was to gain understanding of the activities developed in these pedagogical meetings, specifically the ones related to EAP teaching materials development. As we can see 35 $(68,6 \%)$ of the teachers surveyed declared that these pedagogical meetings somewhat helped them to develop EAP materials, the follow up question asked how.

Figure 20-EAP teaching materials development

\begin{tabular}{|c|c|}
\hline Answers & \multirow{2}{*}{ Study of needs analysis. } \\
\cline { 1 - 1 } $\begin{array}{c}\text { Study of materials that talk about EAP. } \\
\text { By reading articles and discussing strategies to cope with the } \\
\text { challenges we encounter in class. }\end{array}$ & \\
\cline { 1 - 2 } $\begin{array}{c}\text { The coordinator gives suggestions on where to find solutions for } \\
\text { difficulties or problems presented by the teachers. }\end{array}$ & \multirow{2}{*}{ Discussion } \\
\cline { 1 - 2 } $\begin{array}{c}\text { Discussion about the ongoing courses, approaches to deal with } \\
\text { unforeseen things that might happen in class. }\end{array}$ & \\
\hline
\end{tabular}

Horizontes de Linguística Aplicada, ano 16, n. 1, 2017 
Discussions on how to use these materials, which abilities can be developed, the level of proficiency it is aimed at, how to adapt them for the needs of the students.

Suggestion of creating courses focused on this area.

Knowledge sharing and discussion about materials and class plans.

There are always debates on how to develop teaching materials, as well as the strategies used by other teachers teaching the same course. Presentation of the materials developed previously.

Most common problems faced by the teachers, revision of the materials produced and discussion about the development of the classes and what can be improved on them (materials and classes).

Sharing of positive experiences in class, discussion of ideas that can be used in class, and reading of theoretical texts.

Guidance and review by the pedagogical coordinator.

Micro-teachings, workshops, development lectures.

Specific meetings to deal with the development of EAP materials, discussions regarding methodologies, materials, and how to use them in class.

Preparing activities during the meetings, pair and group work (not during the meeting) and presentation on the next one.

Didactic materials and how to teach them.

Reading methodology materials and collective analysis of activities developed by the teachers, and demo classes.

Demonstration on how to use the materials, their pros and cons.

Reflective activities and task development. 
Developing English for Academic Purposes...

\begin{tabular}{|c|c|}
\hline Relevant content for each level. & \multirow{2}{*}{ Others } \\
\cline { 1 - 1 } Critical literacy. & \\
\hline
\end{tabular}

The figure above depicts teachers' responses to the question of how the pedagogical meetings helped them to develop EAP materials. It is possible to perceive that there are some trends in the activities developed in the pedagogical meetings: study of materials, discussions around articles and teaching problems, and practice. We can notice that some pedagogical meetings emphasize the study of EAP or the discussion of materials already developed, while other LwB meetings emphasize more practical aspects such as creating materials and presenting to other teachers, or delivering micro-teachings for the LwB colleagues. It is interesting to compare the practices occurring in the pedagogical meetings with what teachers believe would help them to prepare their classes, which is the topic of the next section.

Figure 21 - Question 17. What activities would you like to see developed in your pedagogical meetings in order to assist you in the preparation of EAP materials?

\begin{tabular}{|c|c|}
\hline This way is satisfactory. & \multirow{6}{*}{$\begin{array}{l}\text { Meetings } \\
\text { are } \\
\text { adequate }\end{array}$} \\
\hline What we do is enough. & \\
\hline It's okay. & \\
\hline I don’t know. & \\
\hline Any since the issue has been addressed and worked. & \\
\hline The support given is enough. & \\
\hline $\begin{array}{l}\text { Some guidance on how to be a better academic or an } \\
\text { introduction to academic language would be quite helpful. }\end{array}$ & \multirow{2}{*}{$\begin{array}{l}\text { Specific } \\
\text { academic } \\
\text { training }\end{array}$} \\
\hline $\begin{array}{l}\text { How to produce materials with academic purposes. Study the } \\
\text { different forms of publication and oral presentation, so that we } \\
\text { can prepare the lessons following a clearer international }\end{array}$ & \\
\hline
\end{tabular}


guideline. The ideal would be to have the tools so that the teacher could create and adapt materials without being tied to a specific material. It would be very interesting to combine different materials, for example, because each class is unique.

I think we're not prepared to deal with the academic public, we are used to language teaching (grammar), but we have not been taught to to deal with the challenges of teaching adults. Everything I learned was through trial and error, talking a lot with other teachers who go through the same difficulties as me. Other courses offer training, the LwB does not, I miss that. In the LwB conference all presentations talked about basic things related to language teaching, however, it is my view that, we already know how to do this. Little has been said about what exactly is or is not within the academic approach.

Although the meetings are not usually aimed at developing materials, the hours for material development, and class planning usually occur with other LwB teachers. However, I would like to have more academic support, more theoretical framework to guide the creation of EAP materials, as well as some research guidance to create these materials. I think that offering courses with academic approach goes beyond putting the word "academic" in the title and should go through more content aimed at fostering critical thinking/academic literacy.

Those that already exist in my LwB centre I consider valid. It is very good to have the exchange of experiences and preparations such as micro-teachings. I think it would also be interesting the "roundtable" format to exchange real experiences (each teacher chooses a real case of EAP course already offered and shares with the rest of the group).

ESP and EAP classes as part of the undergraduate degree.

Watch an EAP class to see the necessary steps.

More specific workshops and discussion with other EAP teachers.

Have classes to develop my academic skills. 
Developing English for Academic Purposes...

\begin{tabular}{|l|}
\hline $\begin{array}{l}\text { Discussion and reflection on activities that develop more formal } \\
\text { writing and speaking since this is connected with EAP. }\end{array}$ \\
\hline Guided workshops to specific subjects \\
\hline Informative workshops on the theme. \\
\hline $\begin{array}{l}\text { Workshop on preparation of materials, with the supervision of } \\
\text { the coordinators, to give practical tips on creating materials. }\end{array}$ \\
\hline
\end{tabular}

Workshops, face-to-face courses on the subject.

Lectures and workshops

Guidance and workshops.

More training/development with this purpose.

Courses on how to adapt materials through different levels of proficiency.

Discussions about curriculum and strategies for preparing materials

Discussion of the organization of teaching materials, to have a more concrete basis to prepare the materials.

More debates and sharing of materials between teachers.

Preparation of demo classes, how to use the textbook as best as possible.

The continuous presentation of alternatives and discussion of work that could support our practice in the classroom.

Preparation of class and theoretical material discussion.

Working together for the development of materials and study experience.

I believe a class observation system, with feedback and 
collective reflections would be useful.

Exercises of guided writing for A2 students

Closer monitoring with direction and assistance in the preparation of materials.

A material on which I can base my classes.

How we can use the materials we already have.

It would be interesting to have more contact with students who have participated in the programme so that we know what difficulties they felt after the course, we could also explore if the courses these students have taken before beginning studies at a foreign university really helped, etc. I would also like to have greater contact between the participating universities in the program, it would be very helpful being able to exchange ideas with teachers from around the country.

A face-to-face conference lasting around two weeks with all the

Opportuniti es to share experience with other LwB teachers. centres

I wish there was a platform where all LwB centres teachers could share all materials used in the classroom.

Anything is good.

The figure above represents a series of suggestions given by the teachers. It is worth highlighting that several teachers mentioned the need for a platform in which they would be able to communicate and share activities with other LwB teachers from all over Brazil. In addition, it is possible to perceive that some teachers also comment on their need for specific EAP development. One teacher even suggests that he/she would like to have EAP disciplines in the undergraduate course. We can also notice that teachers mention not only the need for EAP teacher development, but also classes on EAP genres and academic language. Furthermore, some teachers ask for practical activities like discussion of tasks and teaching practices. 
Developing English for Academic Purposes...

The answers to the surveys have pointed out that EAP development is offered in the context of the Programme. Nevertheless, these development activities are structured differently in each LwB centre. Furthermore, according to LwB teachers, their difficulties when preparing their EAP classes can be attributed to two facts: the first one is that these LwB classes have students from different areas of study; and the second one is the challenge of preparing EAP classes using authentic materials for lower level students. Finally, according to teachers' suggestions, the pedagogical meetings should address issues like study of academic genres and language, material development activities, and micro-teaching practices.

The following section explores in depth the pedagogical meetings of one LwB centre in the south of Brazil through interviews.

\section{Interviews}

We have conducted interviews with four LwB teachers. They all worked at the same LwB centre. Our objective with these interviews was to understand in depth the teacher development practices occurring in one centre and to explore teachers' views of their training. The interviews were conducted in person or via Skype and a set of questions were prepared. Nevertheless, teachers were free to bring more topics to the discussion. Due to space constraints, we present below only excerpts from these four interviews.

Teachers 01 and 04 have been part of the Programme for more than one year, while teachers 02 and 03 have one year or less of experience in the Programme. In their LwB centre, teachers have to attend a weekly pedagogical meeting, however, sometimes teachers might have courses from their undergraduate programmes at the same time as the meetings occur. In these cases, teachers may not have participated in all the activities mentioned. 
Figure 22-Question 1. What happens in the weekly pedagogical meetings?

\begin{tabular}{|c|c|}
\hline $\begin{array}{c}\text { Particip } \\
\text { ant }\end{array}$ & Excerpt \\
\hline $\begin{array}{c}\text { Teacher } \\
01\end{array}$ & $\begin{array}{l}\text { She (the pedagogical coordinator) has been assigning some } \\
\text { activities for us, some of the activities were really nice, while } \\
\text { others were not that interesting. The activities are mainly } \\
\text { creating tasks for the students. We always have to present the } \\
\text { task and comment on each other's tasks. I think that these } \\
\text { micro-teachings are interesting. } \\
\text { Some of the teachers are not participating in these weekly } \\
\text { meetings because of the schedule, but there is usually } 10 \text { out of } \\
15 \text { teachers in the meetings. So it's enough people to comment } \\
\text { and discuss. }\end{array}$ \\
\hline $\begin{array}{c}\text { Teacher } \\
02\end{array}$ & $\begin{array}{l}\text { At this moment, we are creating Learning Objects for a parallel } \\
\text { project from one of the coordinators about two academic genres } \\
\text { (abstracts and article reviews) and tasks for the English courses } \\
\text { of the undergraduate degree in Languages at our university. } \\
\text { Before that, we read articles about developing online teaching } \\
\text { materials and teaching materials in general. We had lectures } \\
\text { about task-based learning and the teachers participated in my } \\
\text { final paper presentation (about the creation of didactic } \\
\text { sequences for teaching Portuguese for Foreigners). The last } \\
\text { meetings were about the development of teaching materials. }\end{array}$ \\
\hline $\begin{array}{c}\text { Teacher } \\
03\end{array}$ & $\begin{array}{l}\text { In the beginning of the year we analysed and prepared didactic } \\
\text { units, so we had to prepare exercises of listening, reading, etc. } \\
\text { We also had some workshops about ESP, especially EAP, we } \\
\text { analysed some articles. We prepared materials for the course of } \\
\text { abstracts and articles. Now, we are preparing some activities } \\
\text { but I'm not sure because I have not been attending the meetings } \\
\text { due to my undergraduate classes. }\end{array}$ \\
\hline $\begin{array}{c}\text { Teacher } \\
04\end{array}$ & $\begin{array}{l}\text { Preparing materials for EAP courses. Firstly, face-to-face } \\
\text { materials; secondly online materials (learning objects). We } \\
\text { created an Academic Genre Manual, and my group and I were } \\
\text { in charge of the article review genre. Today I start teaching an } \\
\text { EAP course for the first time. This was really nice to me } \\
\text { because until then I had not had any experience with academic } \\
\text { genres, not even in my undergraduate degree. When I was }\end{array}$ \\
\hline
\end{tabular}


taking the "English V" course, we studied article review at the same time I was developing the manual. Now we are working with learning objects. Well, actually we were divided in three groups, and my specific group is working with the development of face-to-face tasks for the English courses at our undergraduate degree in Languages and Literatures.

The objective of this question was to have an overview of the activities developed in the pedagogical meetings. As we can see, Teacher 01 mentions creating activities and putting them into practice in the meeting, Teacher 02, 03, and 04 also mentions material development, more specifically the development of learning objects. Nevertheless, as pointed out by Teacher 02, these learning objects are not meant to be used only in the LwB classes.

Figure 23 - Question 2. Is there anything specific in the meetings that help you to develop EAP materials?

\begin{tabular}{|c|c|}
\hline $\begin{array}{c}\text { Particip } \\
\text { ant }\end{array}$ & Excerpt \\
\hline $\begin{array}{c}\text { Teacher } \\
01\end{array}$ & $\begin{array}{l}\text { So far, I don't think so. For me, specifically, I don't feel that the } \\
\text { meetings have helped me directly with this. Especially because } \\
\text { my EAP classes were always A2, I have never had students } \\
\text { who knew a bit more. } \\
\text { So, with A2 students you cannot just bring EAP for them, you } \\
\text { have to bring other things and then enter on EAP and I felt that } \\
\text { the activities developed in the meetings were created for B1 or } \\
\text { B2 students, which can already write in English. At the end I } \\
\text { think, this activity is nice but not for my students. }\end{array}$ \\
\hline $\begin{array}{c}\text { Teacher } \\
02\end{array}$ & $\begin{array}{l}\text { Specially reading, we started with theory, then she (the } \\
\text { pedagogical coordinator) proposed that teachers presented } \\
\text { (microteaching in pairs or groups) tasks they developed and } \\
\text { used on the Program, not necessarily tasks on EAP, since some } \\
\text { teachers do not teach this kind of course. }\end{array}$ \\
\hline $\begin{array}{c}\text { Teacher } \\
03\end{array}$ & $\begin{array}{l}\text { We read articles about EAP and discussed. There were also } \\
\text { some activities for the teachers, for instance, we had to put a } \\
\text { lesson plan in order, we also adapted materials in the meeting. }\end{array}$ \\
\hline
\end{tabular}




\begin{tabular}{|c|l|}
\hline & $\begin{array}{l}\text { We also created our own activities and presented to the other } \\
\text { teachers, kind of a micro-teaching. }\end{array}$ \\
\hline Teacher & $\begin{array}{l}\text { For this course I'll be starting teaching today, I don't think so. } \\
\text { But for developing online materials I learnt a lot since I had no } \\
\text { clue on how to create them. The pedagogical coordinator } \\
\text { brought many websites that teach English online. We analysed } \\
\text { some of these websites in one of our meetings, so at least we } \\
\text { had an opportunity to get to know them. Certainly today in } \\
\text { class I'm going to use them! Oh, there was also a workshop } \\
\text { about a textbook focused on EAP, so I think it will be helpful as } \\
\text { well. }\end{array}$ \\
\hline
\end{tabular}

Even though question 01 inquired about the pedagogical meetings in general, question 02 aimed at emphasizing teacher development for EAP purposes. Teachers' perceptions are varied. Teacher 01 argues that the EAP training she received in the pedagogical meetings does not match the needs of basic level students. Teachers 02 and 03 mention the study of EAP genres and microteaching activities based on this study. Finally, Teacher 04 suggests that the pedagogical coordinator has provided them with extra resources to bring to class, such as websites.

Figure 24-Question 3. Do you develop teaching materials in the meetings?

\begin{tabular}{|c|l|}
\hline $\begin{array}{c}\text { Particip } \\
\text { ant }\end{array}$ & \multicolumn{1}{c|}{ Excerpt } \\
\hline $\begin{array}{c}\text { Teacher } \\
01\end{array}$ & $\begin{array}{l}\text { I remember that we have to prepare something but it wasn't } \\
\text { necessarily of EAP, we could chose if it was something for } \\
\text { general English or EAP. I have created materials for general } \\
\text { English. }\end{array}$ \\
\hline $\begin{array}{c}\text { Teacher } \\
02\end{array}$ & No. I prepare teaching materials at home. \\
\hline $\begin{array}{c}\text { Teacher } \\
03\end{array}$ & $\begin{array}{l}\text { I think we only adapted materials in the pedagogical meetings, } \\
\text { but we had to create materials to present in the pedagogical } \\
\text { meetings. }\end{array}$ \\
\hline
\end{tabular}


Developing English for Academic Purposes...

Teacher No. Usually we have to do something outside the meeting (at 04 home). Sitting together and create materials, no.

Figure 25 - Question 3.a. And did you use this material in your lessons?

\begin{tabular}{|c|l|}
\hline $\begin{array}{c}\text { Particip } \\
\text { ant }\end{array}$ & \multicolumn{1}{c|}{ Excerpt } \\
\hline $\begin{array}{c}\text { Teacher } \\
01\end{array}$ & $\begin{array}{l}\text { Yes, yes. Actually, I have already used, I created these materials } \\
\text { based on something that I had already done with my students. I } \\
\text { have just adapted based on the comments and feedbacks, and } \\
\text { then I used it again. But this was for general English, because } \\
\text { for EAP specifically I don't remember creating materials in the } \\
\text { meetings and using it with students. I know that we discussed } \\
\text { about that, but I can't recall we actually using it. }\end{array}$ \\
\hline $\begin{array}{c}\text { Teacher } \\
02\end{array}$ & $\begin{array}{l}\text { About the Learning Objects, I'm not sure I'll be using them in } \\
\text { class because not many people developed them so far (only I } \\
\text { prepared, as far as I know). It is possible to use this Learning } \\
\text { Objects, but I'm not sure I would use them because I prefer not } \\
\text { to rely on any technological devices when I prepare my classes, } \\
\text { since we never know what rooms we will be using, so I don't } \\
\text { use PowerPoint presentations, internet. For example, I had to } \\
\text { teach one without electric power at the Health building, so if } \\
\text { you rely 100\% on technology... }\end{array}$ \\
\hline $\begin{array}{c}\text { Teacher } \\
03\end{array}$ & $\begin{array}{l}\text { No. } \\
04\end{array}$ \\
\hline $\begin{array}{c}\text { Teacher } \\
\text { I want to use the materials related to article reviews in this } \\
\text { course I'll be offering from today on. }\end{array}$ \\
\hline
\end{tabular}

With this question we wanted to explore what teachers meant by developing materials in the meetings, as it is suggested in questions 01 and 02 . Teachers usually present or adapt materials in the meetings, but the actual development of material occurs in other spaces, such as their houses.

Question 3.a investigated if teachers used these materials discussed in the meetings in their lessons. According to Teacher 01 she 
had already used the material before discussing it in the meetings and after adapting it she has put the material into practice again. Teacher 02 mentions that the learning objects are an interesting topic, but they might not be able to use them due to the technological resources in the classroom they teach their courses.

Figure 26 - Question 4. Where do you get the resources to teach EAP? (Internet, research articles, textbooks, etc)

\begin{tabular}{|c|c|}
\hline $\begin{array}{c}\text { Particip } \\
\text { ant }\end{array}$ & Excerpt \\
\hline $\begin{array}{c}\text { Teacher } \\
01\end{array}$ & $\begin{array}{l}\text { I think it is very difficult, I think it is the worst course for me to } \\
\text { teach because the first time I gave an EAP course I had no idea } \\
\text { what I was doing there. I had a textbook, but then I realized that } \\
\text { there is nothing of EAP in this textbook. It was just a text about } \\
\text { reading and writing. So I started to bring somethings that I } \\
\text { knew about EAP, things like formality and informality, but } \\
\text { these were things that I knew based on my experience with } \\
\text { EAP, things that I have used during university. I did not have } \\
\text { any instruction about EAP. I also got materials from other } \\
\text { teachers, some handouts I copied from another textbook that I } \\
\text { had used as an undergraduate. One of the activities I have } \\
\text { created myself, based on the things that I have learned on task } \\
\text { development for general English. }\end{array}$ \\
\hline $\begin{array}{c}\text { Teacher } \\
02\end{array}$ & $\begin{array}{l}\text { The materials of the Abstract course was the one I created from } \\
\text { scratch. I entered on the program in December, but I only } \\
\text { started teaching at the end of January 2016. I had one month to } \\
\text { prepare my classes, so I looked for free online courses } \\
\text { (MOOCs) on academic writing genres, specially abstracts in } \\
\text { order to learn what an abstract was, because I didn't even know } \\
\text { it theoretically and didactically. So, firstly, I was concerned to } \\
\text { learn about this genres. Secondly, I was worried about how to } \\
\text { teach it. However, the latter was not much of a concern, since I } \\
\text { knew how to create a task, but I had to stop and think the } \\
\text { progression of the course (not what to teach in each class). } \\
\text { Later, I found out that the course was not only about abstracts, } \\
\text { but also about article reviews. Nonetheless, I would not have } \\
\text { time to look for more information about this new genre and } \\
\text { then I used the presentation made by the other teachers in }\end{array}$ \\
\hline
\end{tabular}




\begin{tabular}{|c|c|}
\hline & $\begin{array}{l}\text { previous meetings, presenting an overview of what an article } \\
\text { review was, so if I had to at least show my students something } \\
\text { about article review, I would have that, so I would not develop } \\
\text { materials, I could teach about it. So, I took ideas from these } \\
\text { online courses I took, games, activities. I did not use any } \\
\text { resources from textbooks. I also looked for materials I had as a } \\
\text { student in my undergraduate degree in English, because I } \\
\text { wanted to see what my professor proposed in class. }\end{array}$ \\
\hline $\begin{array}{l}\text { Teacher } \\
03\end{array}$ & $\begin{array}{l}\text { When I started to teach at LwB I've got some teaching } \\
\text { materials from other teachers. I have used these materials to } \\
\text { teach a course for A2 level, but then after that I started to teach } \\
\text { this same course, but for B1 then I realized that I would have to } \\
\text { adapt the material, so I started to take videos, texts, or } \\
\text { vocabulary exercises as extra activities. I also talked to other } \\
\text { teachers who had already worked on the same course to check } \\
\text { if they had more suggestions. For the course based on abstracts, } \\
\text { we had this workshop during the summer, and we had created a } \\
\text { sequence of activities to teach how to write abstracts. It was } \\
\text { rather theoretical, but I have adapted a lot and then I used it. }\end{array}$ \\
\hline $\begin{array}{l}\text { Teacher } \\
04\end{array}$ & $\begin{array}{l}\text { Mainly from the textbook, it is my first source. I usually look } \\
\text { for videos and other things, but I like to use the textbook. }\end{array}$ \\
\hline
\end{tabular}

The objective of question 04 was to investigate whether teachers were developing their own materials, or adapting tasks from other resources. As it was pointed out in the surveys, most teachers stated that they developed their own material; however, a significant amount of teachers also mentioned using handouts from the internet and textbooks. Therefore, this question allowed us to explore this issue in further details with the teachers.

Based on teachers' responses it is possible to perceive that some of them use textbooks or parts of a textbook (Teachers 01 and 04). Even though they view textbooks as inappropriate for EAP, especially in the case of Teacher 01, they adapt it by adding extra resources. Teacher 02 mentions that she created all of her materials because she had some extra time to prepare her classes, while teacher 03 states that he started by using materials developed by more experienced teachers, but soon he started to adapt the materials. One 
key aspect mentioned by the teachers in this question seems to be adaptation of textbooks or tasks. As it was mentioned in the surveys, teachers would like to have a database of activities developed by their colleagues that they could adapt and use in their classrooms. This practice seems to be happening to some extent, and in an informal way, in this LwB centre.

Figure 27 - Question 5. Do you take into consideration students' fields of study when preparing your classes? How?

\begin{tabular}{|c|l|}
\hline $\begin{array}{c}\text { Particip } \\
\text { ant }\end{array}$ & $\begin{array}{l}\text { Excerpt } \\
\text { I always try to think about it, but sometimes the activities do } \\
\text { not work like that. I always try to think about this, especially } \\
\text { for A2 students because they have this difficulty to relate to the } \\
\text { language. These A2 students they are not there because they } \\
\text { want to learn English, they are in class because they have to } \\
\text { read or write an article for their MA or because they have to } \\
\text { take a proficiency test. They have very specific goals. So, I } \\
\text { always think that my students are not there because they like it, } \\
\text { but for obligation. Then I try to make the lessons a bit more } \\
\text { interesting. Therefore, I always try to relate the activities with } \\
\text { their disciplines at university. That's why whenever I ask a } \\
\text { production I ask an open theme, I say things like write } \\
\text { something related to you or with your course. } \\
\text { This activity of summaries that we have done I have asked } \\
\text { them to write a summary about stereotypes of their hometowns. }\end{array}$ \\
\hline Teacher & $\begin{array}{l}\text { I cannot work with all areas in class, but I ask them as } \\
\text { homework to search for the journals of their areas, and this is } \\
\text { part of the percentage of class attendance. So, if they do not do } \\
\text { their homework, they get an "absence". Also, it is part of their } \\
\text { final grade. } \\
\text { I cannot search academic texts from their areas, I tell them "I } \\
\text { don't know how abstracts work in your areas. This format of } \\
\text { abstract that I'm teaching you is purely didactic, maybe it is not } \\
\text { the one you will find in your areas, in your journals". } \\
\text { In my teaching materials there are abstracts of many areas, but } \\
\text { not necessarily their areas. They have to bring to class the } \\
\text { abstracts from their areas, from different journals and for }\end{array}$ \\
\hline
\end{tabular}


Developing English for Academic Purposes...

\begin{tabular}{|c|l|}
\hline & $\begin{array}{l}\text { different purposes (article submissions, conference } \\
\text { submissions, etc) }\end{array}$ \\
\hline $\begin{array}{c}\text { Teacher } \\
03\end{array}$ & $\begin{array}{l}\text { In the first day of class I conduct a needs analysis and ask } \\
\text { students to write their undergraduate course. For the } \\
\text { conversation classes, I let them bring things they are interested } \\
\text { in which usually relates to their undergraduate courses. } \\
\text { Usually for writing courses, I ask students to bring research } \\
\text { articles from their fields of expertise and then we analyze it. }\end{array}$ \\
\hline $\begin{array}{c}\text { Teacher } \\
04\end{array}$ & $\begin{array}{l}\text { Each student has to choose autonomously. I cannot know why } \\
\text { they are choosing that specific article to produce an article } \\
\text { review. It is not worth bringing materials from areas different } \\
\text { from their own. I like asking them to share their academic } \\
\text { experiences with the rest of the group, such as presenting about } \\
\text { their research. }\end{array}$ \\
\hline
\end{tabular}

Teachers have different ways of dealing with the different fields of study in class. Teacher 01, for instance, tries to motivate the students in choosing topics that will interest them; nevertheless, as pointed out by this teacher, these topics might not be necessarily related to students' area of expertise. Teachers 02 and 03 try to use materials from different fields of study in class or as homework. Teacher 04 mentions that students are free to choose one research article in order to write a review. Therefore, they are likely to account for their field of study. It is worth highlighting Teacher 02's comment related to the discipline differences in writing. This teacher feels that he does not have the knowledge on how a research abstract is written in each field of study, but he circumvents this problem asking students to take examples from their fields of study to class.

Figure 28 -Question 6. What difficulties do you encounter when preparing EAP materials?

\begin{tabular}{|c|l|}
\hline $\begin{array}{c}\text { Particip } \\
\text { ant }\end{array}$ & \multicolumn{1}{|c|}{ Excerpt } \\
\hline $\begin{array}{c}\text { Teacher } \\
01\end{array}$ & $\begin{array}{c}\text { I have countless difficulties! I don't even know how to start. I } \\
\text { don't know what themes to bring to class. Nowadays, I can }\end{array}$ \\
\hline
\end{tabular}




\begin{tabular}{|c|c|}
\hline & $\begin{array}{l}\text { plan a whole course, like the sequence of the units. I know that } \\
\text { I have to start teaching how to build a sentence and then evolve } \\
\text { to build an abstract, but it's difficult to create the activities to } \\
\text { achieve these outcomes using resources related to EAP, } \\
\text { especially because has a specific vocabulary for each area and } \\
\text { each student is from one different discipline. I think that } \\
\text { preparing EAP classes is too complex, especially because I } \\
\text { don't have the knowledge about academic writing to help } \\
\text { students. I think I can help A2 students, but more advanced } \\
\text { students I would not be able. }\end{array}$ \\
\hline $\begin{array}{c}\text { Teacher } \\
02\end{array}$ & $\begin{array}{l}\text { I missed basis material on which I could develop my own and } \\
\text { use it as an example, I had no idea how to prepare materials to } \\
\text { teach abstracts. Nobody in the Program had taught me how to } \\
\text { develop tasks or didactic sequences, I had known it from } \\
\text { previous experiences. } \\
\text { There are people who know that someone developed a nice task } \\
\text { to an EAP course, so they ask directly to him or her, so it would } \\
\text { be nice if there was sharing of materials between the teachers. }\end{array}$ \\
\hline $\begin{array}{c}\text { Teacher } \\
03\end{array}$ & $\begin{array}{l}\text { I think that in the LwB context the main problem is the variety } \\
\text { of disciplines represented in the same English class, especially } \\
\text { because some students enroll in one lesson based on their } \\
\text { schedule and not on the objectives of the course. So they enter } \\
\text { a course to write abstract but they are not interested in this. It is } \\
\text { a challenge to make the course interesting for these students. } \\
\text { Another issue is that students can be undergraduate, Master or } \\
\text { PhD students from different disciplines. So, sometimes it's } \\
\text { difficult to accommodate their specificities. }\end{array}$ \\
\hline $\begin{array}{c}\text { Teacher } \\
04\end{array}$ & $\begin{array}{l}\text { I think the biggest challenge is to deal with basic level students. } \\
\text { They already have some restraints regarding their knowledge of } \\
\text { English. For example: "I don't even know how to use English } \\
\text { in my daily life, how should I know how to read an academic } \\
\text { article?", "I don't even know how to write an email to a friend, } \\
\text { how can I know how to write a review?" Sometimes, students } \\
\text { know a lot but they don't know it, so I try to show that they do } \\
\text { know (some) English. }\end{array}$ \\
\hline
\end{tabular}


Developing English for Academic Purposes...

The aim of this question was to explore teachers' difficulties with EAP teaching and materials development. It is possible to notice that the teachers interviewed mentioned recurrently the fact that they do not know how to plan the activities (Teachers 01 and 02). Teacher 03 suggests that having students from different disciplines is sometimes a challenge, and Teacher 04 points out to an issue that had already been raised in the surveys: the difficulty of preparing materials for basic level learners using authentic materials.

Figure 29 - Question 7. What kind of teacher development would you like to have at the pedagogical meetings?

\begin{tabular}{|c|l|}
\hline $\begin{array}{c}\text { Particip } \\
\text { ant }\end{array}$ & \multicolumn{1}{c|}{ Excerpt } \\
\hline Teacher & $\begin{array}{l}\text { I think that preparing a course in its entirety, because we } \\
\text { usually discuss tasks, however I think it would be interesting to } \\
\text { think about the whole curriculum. For example, how do you } \\
\text { prepare reading and writing activities for A2 students? But the } \\
\text { whole course, not only one activity. Because one activity works } \\
\text { for one or two classes, but the problem is the whole course } \\
\text { which lasts for almost three months. We should think about } \\
\text { how we are going to conduct the course, what is the final goal } \\
\text { of this course. }\end{array}$ \\
\hline Teacher & $\begin{array}{l}\text { Mentoring/tutoring between more experienced teachers/the } \\
\text { coordinators and less experienced teachers regarding } \\
\text { development of teaching materials, someone who sits next to } \\
\text { me and says "this is good, this is not so good". Nobody has } \\
\text { evaluated the materials I have been using in my classroom so } \\
\text { far. Apart from one meeting during the summer, the teachers do } \\
\text { not have time to meet during the semester, the weekly meetings } \\
\text { do not offer this opportunity to share materials and experiences. } \\
\text { To sum up, my suggestions are: tutoring the EAP tasks } \\
\text { developed by the teacher and guidance to create these } \\
\text { materials; a reference material to serve as a guideline to } \\
\text { develop new ones, which has already been approved by other } \\
\text { teachers and coordinators. The weekly meetings should be } \\
\text { about all these aspects since it is the moment when everybody } \\
\text { gets together. }\end{array}$ \\
\hline
\end{tabular}




\begin{tabular}{|c|l|}
\hline \multirow{2}{*}{$\begin{array}{c}\text { Teacher } \\
03\end{array}$} & $\begin{array}{l}\text { I think we could have more explanations related to the courses } \\
\text { objectives. For example, now I have to teach a preparatory } \\
\text { course for the TOEFL test and I know how to teach reading, } \\
\text { writing, speaking and listening, but I don't know how to teach } \\
\text { this course } \\
\text { There is a lot of exchange of information and material between } \\
\text { teachers, but this is informal, so it would be better if there were } \\
\text { more formal ways to share activities on each course. I know } \\
\text { that there is a google drive for this centre, but I don't know how } \\
\text { to access it. }\end{array}$ \\
\hline $\begin{array}{c}\text { Teacher } \\
04\end{array}$ & $\begin{array}{l}\text { I like the way things are, presenting materials and readings. If } \\
\text { we could prepare things in the meetings it would be nice too. } \\
\text { Working in the meetings would be more interesting. }\end{array}$ \\
\hline
\end{tabular}

In this question we wanted to have an overview of what teachers thought would help them in delivering EAP classes. As it was mentioned in the previous questions, teachers sometimes have problems with establishing a progression in their courses, therefore Teacher 01 and 03 suggest that it would be beneficial to have some kind of syllabus for the whole course, or a clear description of the course objectives. Teacher 02 mentions the need for some discussion of evaluation of the tasks prepared by the teachers and she suggests that these could be achieved by creating a mentoring scheme between novice and more experienced teachers. Finally, Teacher 04 would like to develop materials in the meetings.

Through the interviews we could notice the reinforcement of some topics discussed in the surveys such as the desire to share the materials developed, the need for teacher development on EAP genres, the difficulties in preparing materials for basic level students, among others. Nonetheless, the interviews also mention other problems that might be particular to this LwB centre such as preparing activities for the whole course and achieving its goals. The aim of this section was to present the responses to the interviews. The next section tries to answer the research questions and provide some suggestions of practices that could be implemented in the LwB pedagogical development. 
Developing English for Academic Purposes...

\section{Discussion}

The objective of this paper was to describe and analyse the teacher development practices developed in the context of the Languages without Borders Programme. Based on the surveys conducted with teachers from different LwB centres we could notice that there is a plethora of activities being developed from research conducted in the field of EAP to materials development and microteaching exercises. In addition, it was possible to perceive that $\mathrm{LwB}$ centres have the autonomy to make decisions regarding the courses offered and this results in a wide variety of topics being covered through all the LwB centres.

Resuming the research questions:

1) What is the profile of $L w B$ teachers in different universities in Brazil?

The majority of LwB teachers are undergraduate students towards the end of their course. They teach mostly basic and intermediate level students from different areas. According to the surveys, they are encouraged to create their own EAP teaching materials for the LwB Programme.

2) What activities are developed as part of their teacher development programmes in the LwB centre?

In the surveys and interviews teachers mention: study and discussion of academic texts; workshops on how to develop tasks or prepare and adapt teaching materials; presentation and discussion of tasks. Based on teachers' responses we can also argue that their development goes beyond the pedagogical meetings. It continues when they develop materials with their peers, or adapt textbook tasks or activities developed by their colleagues.

3) What are teachers' difficulties when preparing EAP materials to be used in the LwB context?

As mentioned by Teacher 01 in the interviews there are plenty of difficulties. Based on the surveys, teachers find it difficult to keep 
the class interesting for all the students when they have students from different areas of expertise in class. Furthermore, teachers mentioned that using authentic materials, one of the principles of EAP teaching according to Robinson (1991), might present a problem for basic level students, which are the majority of students enrolled in the Programme according to the answers to question 06 of the survey.

Considering the interviews, another interesting topic has been raised, which is the development of the course curriculum. As mentioned in section 03, in the LwB Programme teachers are the curriculum developers, and the ones who transpose the language to the classroom. Nevertheless, it seems that their teacher development is not fulfilling their needs as curriculum developers, as pointed out by teachers 01 and 02 in the interviews. Sometimes teachers are unaware of the objective of an English course, or do not know how to achieve them in a sequence of activities.

4) What teacher development activities would they would like to be developed in the pedagogical meetings in order to help them prepare their classes?

Teachers suggested a wide range of practices that could be developed in their pedagogical meetings. While some teachers are satisfied with their teacher development programmes, others think that they would benefit from the study of academic language and genres in order to use that knowledge into creating their materials; other teachers also mention the possibility of developing materials in the pedagogical meetings, or discussion of the tasks developed; some teachers would also like to have practical activities in the meetings like teaching to their colleagues and receiving feedback.

In addition, some of the suggestions are not specifically related to the face to face teacher development, but with other pedagogical aspects of the LwB Programme. In the first place, the need to create a platform in order to share the activities developed in the context of the Programme is pungent. Considering that LwB employs several teachers all over Brazil and the majority of them are developing their own tasks it would save time and give room to discussion of the tasks if these were shared among teachers. 
Developing English for Academic Purposes...

Moreover, the teachers interviewed point out to the fact that the autonomy that they have might also be a problem as they are free to create their own curriculum they sometimes feel unprepared to develop a sequence of activities, therefore this is another activity that could be developed in the pedagogical meetings.

Finally, even though the pedagogical development offered by the LwB Programme still has a substantial room for improvement in order to fulfill teachers' needs it seems, based on the answers given, that it is already providing support for them to learn how to become EAP teachers.

\section{References}

BRASIL. Universidades participantes do Núcleo de Línguas - Inglês. Disponível em:<http://isf.mec.gov.br/ingles/images/2015/janeiro/Universidades_N ucLi 2015 novo.pdf $>$. Acesso em: 03 de Set. 2016.

BELCHER, D. Trends in teaching English for specific purposes. Annual Review of Applied Linguistics, n. 24, p. 165-186, 2004.

CARNOY, M. University expansion in a changing global economy: the triumph of the BRICS? Stanford, California: Stanford University Press, 2013.

CRISTOVÃO, V.; BEATO-CANATO, A. A formação de professores de língua para fins específicos com base em gêneros textuais. DELTA, n. 31 , v. 1, p. 45-74, 2016.

JOHNS, A.; PRICE-MACHADO, D. English for Specific Purposes (ESP): tailoring courses to student needs - and to the outside world. In: CELCE-MURCIA, M. (Ed.), Teaching English as a second or foreign language. Boston: Heinle \& Heinle, 2001. p.43-54.

JORDAN, R. The growth of EAP in Britain. Journal of English for Academic Purposes, v. 1, n. 1, 2002, p. 69-78. 
HYLAND, K.; HAMP-LYONS, L. EAP: issues and directions. Journal of English for Academic Purposes, v. 1, n. 1, 2002, p. 1-12.

HYLAND, K. General and specific EAP. In: HYLAND, K.; SHAW, P. The Routledge handbook of English for academic purposes. London: Routledge, 2016. p. 17-29.

ST JOHNS, A.; DUDLEY-EVANS, T. English for specific purposes: international in scope, specific in purpose. TESOL Quarterly, v. 25, n. 2, 1991, p. 297-314.

NETO, T.; SENHORAS, E. Diplomacia e para-diplomacia educacional brasileira no contexto da ciência, tecnologia e inovação. Revista Mundorama. 2014. Disponível em: <http://mundorama.net/2014/09/06/diplomacia-e-paradiplomaciaeducacional-brasileira-no-contexto-da-ciencia-tecnologia-e-inovacaopor-eloi-martins-senhoras-tercio-araujo-da-silva-neto/>. Acesso em: 03 set. 2016.

ROBINSON, P. ESP today: a practitioner's guide. Hemel Hempstead: Phoenix, 1991.

Recebido em: 18/01/2017

Aceito em: 16/05/2017

Título: O desenvolvimento de materiais didáticos de Inglês para Fins Acadêmicos (IFA): uma análise das necessidades de professores iniciantes 